\title{
Bidding at the prison auction house: An exchange of prisoners' and university students' perceptions of crime and punishment
}

Kate J. DuBois

West Virginia University

Follow this and additional works at: https://researchrepository.wvu.edu/etd

\section{Recommended Citation}

DuBois, Kate J., "Bidding at the prison auction house: An exchange of prisoners' and university students' perceptions of crime and punishment" (2009). Graduate Theses, Dissertations, and Problem Reports. 838. https://researchrepository.wvu.edu/etd/838

This Thesis is protected by copyright and/or related rights. It has been brought to you by the The Research Repository @ WVU with permission from the rights-holder(s). You are free to use this Thesis in any way that is permitted by the copyright and related rights legislation that applies to your use. For other uses you must obtain permission from the rights-holder(s) directly, unless additional rights are indicated by a Creative Commons license in the record and/ or on the work itself. This Thesis has been accepted for inclusion in WVU Graduate Theses, Dissertations, and Problem Reports collection by an authorized administrator of The Research Repository @ WVU. For more information, please contact researchrepository@mail.wvu.edu. 
Bidding at the Prison Auction House:

An Exchange of Prisoners' and University Students' Perceptions of Crime and Punishment

\author{
Kate J. DuBois \\ Thesis Submitted to the \\ Eberly College of Arts and Sciences \\ at West Virginia University \\ in partial fulfillment of the requirements \\ for the degree of \\ Master of Arts \\ in \\ Applied Social Research
}
Corey Colyer, PhD, Chair
James J. Nolan, PhD
Rachel Stein, PhD

Division of Sociology and Anthropology

\author{
Morgantown, West Virginia \\ 2009
}

Keywords: labeling; prisons; programming 


\begin{abstract}
Bidding at the Prison Auction House:

An Exchange of Prisoners' and University Students' Perceptions of Crime and Punishment
\end{abstract}

Kate J. DuBois

During the spring of 2006, a new program was instated at West Virginia University that provided an arena for undergraduate Criminology majors and residents of a correctional facility to discuss and learn about issues within the criminal justice system. The class took place at a correctional facility. After leaving the class, the students were expected to write a reflection paper on the discussions that took place within the classroom to return at the next session. The purpose of this research is to conduct a thorough analysis of the reflection papers of each student across the 15 weeks. The findings suggest that there are vast differences between the groups' opinions with regards to the social construction of "criminal" labels. More specifically, it is harder for the residents of the prison to change their perceptions their "criminal" identities. On the other hand, the findings show that there is little difference in opinion about the purposes of prison - or its relative effectiveness - between the two groups. 


\section{TABLE OF CONTENTS}

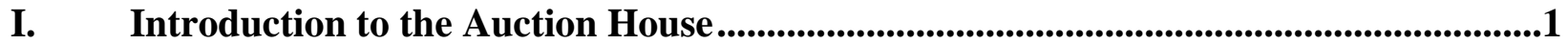

II. Literature Review

a. Social Construction of "Crime" and "Criminal”................................................4

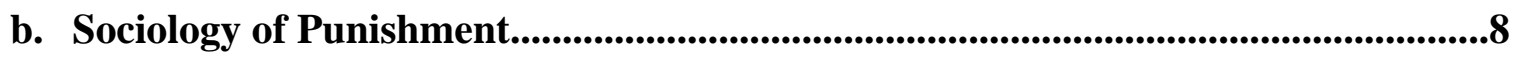

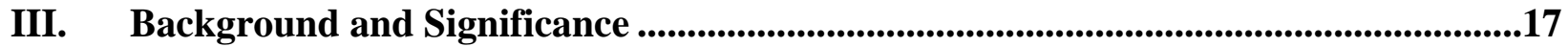

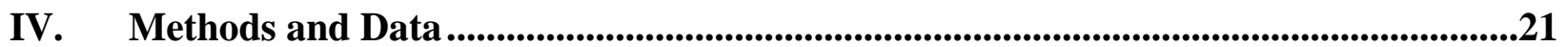

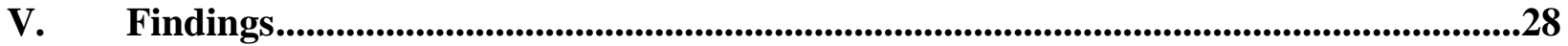

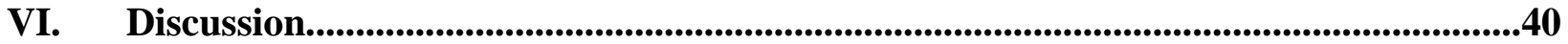

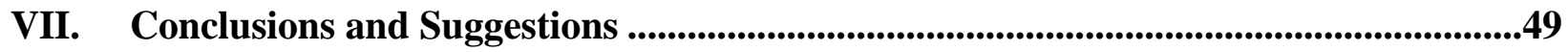

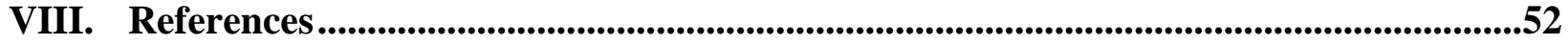

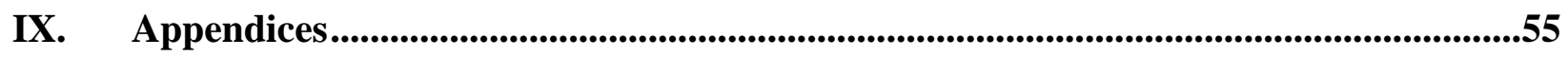

Appendix A - Students' Comparative and Contrasting Perceptions of the Purposes of Prisons

Appendix B - Acceptance of "Crime” and "Criminal” Labels Matrix Appendix C - Purposes and Consequences of Prison Matrix 


\section{Bidding at the Prison Auction House: An Exchange of Prisoners' and University Students' Perceptions of Crime and Punishment}

On January 20, 2006 a group of eight undergraduate students found themselves sitting in the stuffy administration building of a state prison in rural West Virginia. One student looked around the room and saw seven other West Virginia University students with frightened faces, much like his own. The chairs in the room were arranged in a circle, and between each university student sat an empty chair. As the huge metal door to the room opened, every soul in the room inhaled at the same time. In walked a sullen line of four females and five males, all dressed in khaki shirts and pants. The only distinctive feature of each individual was the numbers printed on their chests. Each person in the room, university student and resident of the correctional facility, had fears and assumptions about the "other” group. This was the first day of the Issues in Crime and Justice Course. Fortunately, these students were given 15 weeks to break down those walls of fears and assumptions, brick by brick.

It was during this unique experience that the criminological theories and issues from the classroom began to connect with "real life". The idea of a "criminal” or even the idea of a prisoner was no longer a foreign concept debated among peers. Rather, they were real living, breathing human beings with opinions, hopes, fears, and stories that needed to be heard - and who eventually, became friends and colleagues. Unfortunately, the class did not reach cohesion and solidarity right away, but rather they had to work every week to reach a level of trust.

One university student coined the phrase "auction house” to describe the structural appearance of the first meeting:

We had no specific subject to discuss. A few of the inside students began to speak and it was like an auction house. The conversation was going a mile a minute...It seemed as if the inside students had so much to say about the issues directly pertaining to them. During this period, the outside students were relatively quiet, not able to fit in a comment... (Outside Student: Week One) 
Auctions are normally loud, fast and confusing environments. There is one person, the auctioneer, who is controlling the situation, while the audience is competing for his or her attention. Within this particular auction house at the prison facility, the professor is the auctioneer "onstage" leading the discussions. The students would be the audience competing for his attention. However, this particular student states that the inside students were the ones competing while the outside students remained silent. The outside students were primarily observers of the "auction". Why were they silent, but the insiders so audible? Perhaps they felt these are not their issues to bid on; or perhaps they are simply afraid to be heard.

Many of the university students had probably never met or known anyone who was incarcerated. The only images they had to go on are those they had seen in the media or read about in books. Therefore, they were not entirely sure what to expect. An outside student expressed surprise by the inmates' openness and friendliness. He stated, “It went from talking to an inmate, to talking to a regular person on the street”.

Much like this outside student, a few other students stated they began to relax and feel comfortable with one another. In the beginning of each class, the professor led an "ice-breaker" activity. Although the main purpose of the activity was to get to know one another, the latent function of the activity was to begin to break away the initial tension and nerves. Many students saw the professor's forced interaction and manipulation of the situation as a factor in alleviating some of the anxiety. And they felt as though this anxiety was lessened at the very beginning of the class.

From this discussion, it seems as though the feeling of solidarity increased as the course continued. As the students spent more time with one another, they were able to begin identifying with one another. By identifying with one another, interactions became more open and less 
constrained. Through this level of comfort, the students also began building trust amongst one

another. In the second week, an outside student stated,

During the first class discussion, the inside students carried the conversation, however last week the outside students were able to participate more in the class discussion. The inside students were happy to hear from us and were surprised that we (both inside and outside students) shared a lot of the same views. (Outside Student: Week 2)

These positive interactions among these students seemed to only increase as the weeks

passed. In her final paper, one inside student stated

I see the outside students showing sincere empathy at the barriers the inside students must bear...This shows me hope as I've watched the metamorphosis of the outside students. The outside students represent the views and ideas, on a small scale, of society. I've watched as I hear their views changing accepting me as an individual realizing good people can make bad decisions. (Outside Student: Week 15)

Each week, the students (both inside and outside) would meet and discuss a topic that was prompted by the professor. After leaving the class, the students were expected to write a reflection paper on the discussions that took place within the classroom to return at the next session. Overall, the students turned in roughly eight papers each. Through these students' papers, one is able to gain a unique view into the feelings and perceptions of each student as they experienced the Issues in Crime and Justice Course.

The purpose of this research is to conduct a thorough analysis of the reflection papers of each student across the 15 weeks. Through the analysis of these students' "observations" and "reflections", this research attempts to explore the differences in perceptions of crime and punishment between the two groups. Additionally, the research provides a conceptual framework of the issues which seemed most important and most discussed during the course. 


\section{LITERATURE REVIEW:}

As the "Findings" section of this research will illustrate, there were two important themes which emerged from the data: the construction of "crime" and "criminal” labels and the purposes of prison. The following is a brief but thorough introduction to the governing literature on the subjects. Also provided through this review are the criticisms and limitations of each theoretical perspective.

\section{The Social Construction of "Crime" and "Criminal"}

Within all societies, there is a general consensus of what a crime is, what a criminal is, and who is a criminal. These are not concrete or tangible ideas that can be empirically identified. Rather, they are socially created "realities". The reality of what are considered serious or dangerous crimes (and criminals) is constantly changing and redefined. Moreover the appropriate punishments for these “criminals” continually changes.

Reiman (2007:62) came up with a solution or "cure” for crime: simply "throw out all of the criminal laws”. By stating this, Reiman is simply trying to illustrate that without criminal laws there would be no crime. In turn, without criminal laws there would be no criminals. This brings us around to Reiman’s concept of the “carnival mirror”.

Our criminal law labels some acts “crimes”. Through this labeling process, it identifies some acts that pose such a threat to society (and its members) that we should be protected from these actions. “This does not mean that criminal law creates crime-it simply mirrors real dangers that threaten us” (Reiman 2007:62). The same can be said for the entire criminal justice system. "If police did not arrest, or prosecutors charge, or juries convict, there would be no ‘criminals’” (Reiman 2007:62). 
The trick or concern with this "mirroring” process is the reliability of the reflection.

Through our institutions, we members of society rely upon our criminal justice system to choose from what we need be protected. Kai Erikson (1962) agreed with the idea that deviancy would not be a reality without the public’s acknowledgement of its existence. He stated,

Deviance is not a property inherent in certain forms of behavior; it is a property conferred upon these forms by the audiences which directly or indirectly witness them. Sociologically, then, the critical variable in the study of deviance is the social audience rather than the individual person, since it is the audience which eventually decides whether or not any given action or actions will become a visible case of deviation. (Erikson 1962:309)

Reiman (2007:62) asserts that "the American criminal justice system is a mirror that shows a distorted image of the dangers that threaten us —an image created more by the shape of the mirror than by the reality reflected”.

After reviewing this argument, there came one clear example of this theory: war on drugs. During the 1980s Reagan’s administration declared a “war on drugs” (Musto 1999). To them, drug-related acts were worthy of a heightened level of seriousness. They believed that these actions were so threatening to society that we needed to be given more protection from them. What was the result of this declaration? An enormous rise in the prosecution and incarceration of those individuals arrested for drug-related charges. These increases were seen by higher incarceration rates of the poor, the minorities, the young and an enormous increase in the number of women behind bars (Musto1999). By changing the seriousness of drug-related acts, the vigor with which these individuals were sought out and charged changed. Moreover, there was a change in the demographic characteristics of "criminals". The criminal justice system mirror was reshaped to include this image of drug-related acts.

The students within the Issues in Crime and Justice course also discussed the construction of the label "criminal". It was very interesting to find that even the inside students rely on the 
"carnival mirror", and define themselves as "criminals". Therefore, not only are those outside of the criminal justice system accepting our society’s definition of "crime” and "criminal”, but so are those who are most affected by the system.

The idea that those being labeled as a "criminal” must also accept the "carnival mirror" and its reflection of whom is "criminal" is most understood by way of labeling theory. Becker's (1963) theory of labeling rests upon the assumption of a power struggle between those with the power to label (policy makers) and those who are actually labeled as deviants or "criminals". This process of determining who is deviant or "criminal" is not just a simple matter of deciding and labeling, but rather a process which has been discussed by many labeling theorists. First, a "criminal” individual must participate in some sort of deviant behavior or "primary deviance" (Becker 1963). One important component of this step is that the individual must be caught. This goes back to the importance of the "social audience" described by Erikson (1962). There must be someone who witnesses this individual's deviant action in order for labeling to ever take place. These offenders accept the label "criminal" and begin to internalize it. Before long, if not already, they will assume the duties that the role of a "criminal" requires.

An individual's undertaking of the "criminal” or deviant role is contingent upon others' interactions with them. More specifically, the offender's social circle must also treat him or her as a deviant. And these interactions and assumption of roles will help to fuel further acts of deviance. The continuance or reoccurring of deviant acts by the labeled individual is known as “secondary deviance” (Becker 1963).

Another important component between the two stages of primary and secondary deviance is the change of an individual's status. During this phase of the labeling process, deviants will undergo what is termed as a "degradation ceremony". This "ceremony” is the formal stripping 
of prior statuses and their subsequent replacement with their new “criminal” or “deviant” status. Garfinkel (1956:420) stated, “Any communicative work between persons, whereby the public identity of an actor is transformed into something looked on as lower in the local scheme of social types, will be called a 'status degradation ceremony’”. By way of labeling a person as “criminal” or deviant, one’s master status will also transform during this process. Everything else about their identity - whether it is their career, race, or other identifying characteristics unique to them - will fade in to the background of their new criminal identity.

Charles H. Cooley (1964) also chose to use a metaphor of mirrors to explain this process. He stated that an individual develops a sense of self through the mirrored image of others' views of them. Therefore, if the offender realizes the rest of society sees him as a “criminal”, he will eventually adapt this view of himself via the "looking-glass self”. "The self-image reflected in a mirror is a metaphor for perceptions of self determined through the collective eyes of others (Miller, Schreck, Tewksbury 2007:154)”.

After society and the offender accept this new deviant identity, the question becomes how to deal with the individual and their behavior. Should the individual be given a second chance? Should this individual be punished for their actions? Or should we attempt to correct the undesired behavior? The answers to these questions depend upon the current shape of the criminal justice system's mirror. The consequences of one’s actions depends upon a number of factors - age, number of offenses, type of offense - which are factored into this image of what is “just” and fair. The purposes and forms of punishment have been continually changing and reshaping for hundreds of years. 


\section{The Sociology of Punishment}

In order for one to understand the purposes of prisons in modern society, the purposes and history of punishment should be evaluated. David Garland (1991:1) suggests that in order to fully understand the purposes, means, and forms of punishment one must employ a “multidimensional account of punishment's social forms, functions, and significance”. This enmeshment involves a combination of perspectives from all traditions, so as to avoid the criticisms a singular tradition may receive. Garland draws from three main sociological perspectives - Durkheimian, Marxist, and Foucauldian.

More generally, Garland (1991) describes and contrasts three different perspectives of punishment: penology, philosophy, and sociology of punishment. The first two perspectives are self-exhaustive, and in Garland's view, useless without the other. The penological perspective "views punishment more or less exclusively as a technique of crime control” (Garland 1991:116). The most important objective within the penological approach is to find the cheapest and most effective way to control crime and criminals. Although this perspective is very useful in the evaluation of current policies with regards to the more technical aspects of punishment, it tends to ignore the impact of outside political and economic forces. Garland (1991:117) argues that this view oftentimes can contribute to "inappropriate and unrealistic expectations on the part of the public and the authorities, which add to the penal system's difficulties rather than resolving them". The penological view analyzes methods of punishment as an autonomous sector functioning outside the realms of society. Garland (1991:117) states “...it is inconceivable that any penal system could be disengaged from social forces such as these, and it therefore makes little sense to view punishment as if it somehow stands outside of society and is 
only occasionally affected by it”. Every social institution is effected by outside forces which are not able to be controlled or ignored.

Conversely, the philosophical perspective is more concerned with the moral issues of punishment. Its objective is to justify the use of current modes of punishment. Rather than focusing on the more technical ends of punishment, philosophical perspectives of punishment fall under the more ethical end. Philosophy views punishment as a moral problem in which we must continually evaluate whether current practices are justified or moral. Under the philosophical perspectives

Punishment is viewed primarily as an instance of state coercion and an infringement on individual freedom and therefore triggers a number of arguments about the general justifications of state power (usually some version of the social contract), about the circumstances justifying particular punishments (usually the perpetration of harm to others), and about the proper purposes of measures of this kind (usually the prevention of further harms) (Garland 1991:118)

Although the philosophical perspectives of punishment are invaluable to the assessment of current penal policies, they do have limitations as well. Penal philosophy has very little to offer about the actual forms of punishment - whether capital or corporal punishments are acceptable. The philosophy of punishment tends to view and analyze punishment as an entire social phenomenon, without breaking it down into its separate forms.

Although these perspectives help formulate a theoretical framework in which to think about punishment, they are not always completely accommodating alone. But rather, these two perspectives are most obliging by merging together to form a more complete view of punishment. Garland (1991:119) thinks that the sociology of punishment does exactly that by viewing punishment as “.... a cultural and historical artifact that may be centrally concerned with the control of crime but that is nevertheless shaped by an ensemble of social forces and has a significance and range of effects that reach well beyond the population of criminals”. The 
sociology of punishment views punishment as a social institution-a complex arrangement of social roles and relationships working to establish some type of common goal or need—which provides a combination of the benefits of the philosophical and penological perspectives of prison.

The sociology of punishment allows for an analysis of the past and current forms and means of punishment. Through these analyses, one is also able to make assessments about the relative morality, utility, and effectiveness of the different forms of punishment. Additionally, one is able to recognize the outside influences (i.e. social and political) which have fueled these changes in the forms of punishment. All of these aspects of punishment are constantly manipulating and interacting with one another. Although the sociological view of punishment is a holistic perspective, it is still not made up of a singular, all encompassing theory. Instead, it is a combination of theories guided by a multitude of underlying assumptions of the influences and purposes of punishment — whether it is the influence of power, economy, or the collective conscience. The following section explores these varying perspectives and evaluates their differences and similarities.

Durkheimian Perspective. Emile Durkheim (1933, 1973, 1983) viewed punishment as a mechanism which functioned to uphold the values, beliefs, and morals of the rest of society. Although punishment was meant to control crime, it was also to create "social solidarity" (Durkheim 1983). This is much like Reiman’s (2007) carnival mirror discussed in earlier sections. Punishment is meant to reflect those morals and views of the collective society. Furthermore, by carrying out its policies, punishment reinforces those views daily. Durkheim felt that when offenders violate those norms of the collective society it would provoke “collective moral outrage” (Garland 1991:122). “In Durkheim’s view, the rituals of punishment 
are directed less at the individual offender than at the audience of impassioned onlookers whose cherished values and security had been momentarily undermined by the offender's actions” (Garland 1991:123). Much like Erikson’s (1962) views of deviancy, this moral and social process of punishment strongly depends upon the social audience.

And finally, it is important to note an additional characteristic of Durkheim's (1933, 1973, 1983) perspective of punishment. Most theorists (contemporary and non-contemporary) agree, and oftentimes discuss how the forms and purposes of punishment have gradually changed through the decades. Durkheim saw change in the forms of punishment (i.e. punishment as spectacle to privatized punishment) rather than a change of these fundamental functions of punishment. Therefore, his theory of punishment can be applicable to punishment today and punishment before the birth of the penitentiary. Durkheim felt his views were holistic because punishment policies and the society's view of punishment were always reflected in the "conscious collective"; and consequently, these were reflected within the punishment policies of the time.

As with any theory, there are limitations within the Durkheimian view of punishment. Garland (1991) outlines three particular drawbacks. First, Garland feels that the current (and past) penal policies do not actually reflect the views of the collective society. Instead, Garland sees the current penal policies as reflecting the ideals and agendas of the ruling political groups. "In this respect, institutions such as law and punishment should not be seen as merely reflecting values that everyone already holds. Rather, they are active, value-imposing agencies whose practices play a crucial role in winning support for the dominant morality” (Garland 1991:125). This leads us into Garland's second criticism of Durkheimian perspectives. 
Under Durkheim’s (1983) perspective, the current laws and policies on punishment are a reflection of the society as a whole. This untainted reflection of society seems to be a bit naïve; because it is not ordinary citizens who are enacting and creating these policies, but rather the elected politicians and officials. Therefore it would seem that the policies are actually a reflection of the ruling majority's views - whose views supposedly reflect those of the members of its society. Unfortunately, those reflections by the ruling majority are not always as pure and accurate as we would hope.

The final limitation to Durkheim's perspective of punishment, as noted by Garland (1991), deals with Durkheim's examination of the public's active participation in punishment. This may have been so during the periods of punishment within the public arena; however, today punishment happens more behind the scenes - or literally, behind the walls of penitentiaries. Garland (1991:125) suspects this as a difference in the “declaration” and “delivery” of punishment. Today the public is more active in the earlier stages of the criminal justice process (i.e. trial), but has little say after the final sentencing decisions. After the sentencing stage, the power and responsibility of punishment is turned over to the prison officials. "Indeed one might argue that modern punishment operates a two-pronged strategy - one aimed at expressing, educating, and reassuring public sentiment (which is the one Durkheim describes) and another aimed more directly at regulating deviant conduct, about which Durkheim has relatively little to say” (Garland 1991:125).

Marxist Perspective. A second and equally important authority on the topic of punishment is the Marxist perspective. Within Garland's (1991) explanation of the perspectives of punishment, he uses two separate works instead of the original works of Marx himself. These authors focus on the "political economy of punishment" within their analyses. The first 
perspective is of Rusche and Kircheimer (1968), who focus on "[explaining] why particular penal methods come to be selected and used at particular moments in time and to what extent the pattern of penal development is determined by 'the basic social relations' (by which they mean the mode of production)" (Garland 1991:128). Again, this brings us back to an analysis of the change in forms and means of punishment over time. Furthermore, as with most sociological perspectives of punishment, Rusche and Kircheimer (1968) accept that punishment is meant to control crime but do not focus solely on this aspect of punishment. These Marxist theorists view punishment as a mechanism used to control the working class of society. As such, punishment policies are a mere byproduct of the class struggle so thoroughly discussed and analyzed by Marxists.

Rusche and Kircheimer (1968) see the labor market as the "leading influence on the choice of penal methods" (Garland 1991:129). Thus, the changes in penal methods tend to imitate the changes in the labor market of the same period. "During periods when labor is in abundant supply, penal institutions can afford to be reckless with human lives, leading to the widespread use of corporal and capital punishments (Garland 1991:129)”. Conversely, when society depends upon and needs the labor of those individuals, the penal policies support more humane and appropriate allocation of resources (the prisoners).

A second author under the Marxist perspective mentioned by Garland (1991) is E.B. Pashukanis (1978). He postulates that punishment policies reflect the bourgeois values following the capitalistic form of exchange. As such, he views punishment as a form of exchange. An offender is paying off his debt to society, or the victim. Pashukanis sees this exchange as imitating the "basic ideological forms of capitalist society in the face of actualities such as inequality, unfreedom, and destitution” (Garland1991:131). Through this exchange, the 
bourgeois are able to place a value on human life and human sacrifice. Garland (1991:131) states "Thus although the prison...has its uses as a repressive instrument of class domination, it also operates as an ideological apparatus, helping to reproduce the mental and cultural categories on which capitalist rule depends”.

Again, these perspectives do contain some limitations. First, Garland (1991) sees these perspectives as ignoring additional factors, besides the political and ideological agendas, within society. Although their explanations in the change of penal policies is commendable and important, they seem (as did Durkheim (1983)) to disregard the movements within the social sciences and humanitarianism. Instead, these authors seems to place responsibility directly and solely into the hands of the ruling class. And finally, Garland (1991:133) points out that there is "strong evidence that criminal law commands a wide degree of support among the popular classes, who frequently perceive it as protecting their interests”. So these lower class individuals who are said to be repressed by the upper class's interests and influence on penal policies actually feel protected and included within these policies’ agendas.

Foucauldian Perspective. It is next to impossible to speak on punishment without including the perspectives of Michel Foucault. His study (1977) lead to a movement towards looking at and talking about punishment in a whole new light. Even the feminist critics of his work could not deny his influence. "Foucault played a pivotal role in freeing penality from the confines of a traditional penology's narrow, empiricist obsession with issues of technical efficiency” (Howe 1995:114). Foucault (1977) acknowledged the importance of separating the structure of punishment and its forms from the common way of comparing it to the structure of society. Unlike other authorities on the subject, Foucault (1977:136) felt it was important to study punishment "with a view to its positive effects, however marginal or indirect, and not 
simply as a repressive mechanism”. Finally, Foucault saw punishment as having a major influence on the emergence of the behavioral and social sciences.

As with the Durkheimian and Marxist perspectives, Foucault (1977) focused on the changes which had occurred within the realm of punishment. Foucault (1977:8) turned his attention to the "disappearance of punishment as spectacle”. No longer are individuals convicted of crimes subjected to sanctioned public humiliation and torture. But rather, the punishment end of criminal justice is undertaken beyond the public's eye. Foucault saw this movement as the evidence of justice’s shame in punishing, so they redistributed responsibility to others. “Those who carry out the penalty tend to become an autonomous sector; justice is relieved of responsibility for it by a bureaucratic concealment of the penalty itself” (Foucault 1977:10).

Foucault (1977) also described this change as a movement from punishment of the body (spectacle) to punishment of the soul. Now, there are strict rules and policies regarding access to the offender's body. "Physical pain, the pain of the body itself, is no longer the constituent element of the penalty. From being an art of unbearable sensations, punishment has become an economy of suspended rights (Foucault 1977:11).” To Foucault, evidence of this progressive change could be seen through the use of the guillotine. The guillotine provided one solid strike to the body, ending life. And it did not require the executioner to physically touch and torture the body; but instead, they simply pressed a lever and the punishment was concluded.

Foucault saw the modern penitentiary as exerting a power of discipline, with influence from the Army and monasteries (Garland 1991). The prison officials attempt to force the prisoners to become obedient under their constraints and rules, until eventually this obedience and discipline becomes automatic to the offenders. This obedience is so important that if 
offenders do fall into what the officials deem as appropriate, they may be granted an early release.

Like many others, Foucault (1977) saw that these positive intentions of the modern prison had failed. These failures could be seen from the increasing incarceration rates due to the increasing recidivism rates and the inability to actually reduce crime. However, under all of these failures, Foucault saw a "political success". "The creation of a recidivist delinquent class is deemed to be useful in a strategy of political domination because it works to separate crime from politics, to divide the working classes against themselves, to enhance the fear of prison, and to guarantee the authority and power of the police” (Garland 1991:138). These points lead to the frequent assumption that prison helps to manage the lower classes.

Yet again, this theory does not escape without some criticism.

In focusing on the relations of power and knowledge that structure modern punishments, Foucault neglects other issues such as sensibilities, moral values, and emotional forces that form the cultural framework in which penal power is exercised, the social support and political legitimacy on which penal measures depend, and even the day-to-day political struggles and negotiations that shape penal policies and institutional regimes. (Garland 1991:139)

As with the Marxist perspective, it seems as though there is tendency to ignore the impact of the evolving values of the society. Although Foucault's (1977) theory is less technical than the penological perspective on punishment, it does not include the impact of the use of discretion and concession within the actual management of the penitentiaries. Garland (1991) pointed to another theorist to fill this void, Norbert Elias (1978). While many theorists account for the changes in punishment as a mere reflection in the changes of political and power agendas, Elias brings up the influence of cultural values and "sensibilities". "There is thus a whole range of possible punishments that are simply ruled out as 'unthinkable' because they strike us as 
impossibly cruel and 'barbaric' - as wholly out of keeping with the sensibilities of modern civilized human beings” (Garland 1991:143).

As these three perspectives have illustrated, it is impossible to discuss the sociology of punishment without including each with its respective limitations. All perspectives taken into consideration, one can find a more holistic and complete view of the punishment phenomena and its progression over time. Some things are consistent amongst all of these perspectives:

punishment has and is still evolving and that punishment should be viewed as a social institution not immune to outside influences.

The preceding literature review is a compilation of the two most important themes which emerged from the discourse: construction of "crime" and "criminal" and the purposes of prison/punishment. This literature reviewed the effects of the society functioning outside of the criminal justice system, as well as the inner workings of the criminal justice system itself. This research attempts to study these interactions on a more individual level. More specifically, the discourse provides the perspectives of those moving through the criminal justice system and the perspectives of the members of society who are on the outside of the criminal justice system. By analyzing the friction and differences between the two groups' perspectives, this research can provide a more concrete observation of how these issues are negotiated and constructed on a day-to-day basis.

\section{BACKGROUND AND SIGNIFICANCE:}

\section{The Issues in Crime and Justice Program}

During the spring of 2006, a new program was instated at West Virginia University within the Division of Sociology and Anthropology entitled Issues in Crime and Justice. This program was under the supervision and direction of Dr. James J. Nolan. The purpose of this 
program was to provide an arena for undergraduate Criminology majors and residents of a correctional facility to discuss and learn about issues within the criminal justice system. A prison in rural West Virginia agreed to facilitate the program. The class took place once a week for 15 weeks at the facility's administration building. The class was compiled of nine students from the facility and eight students from West Virginia University.

Although this is a unique program, it was structured must like any other college course. The instructor provided the following reading list: Crime and Punishment (Dostoesky 2003), Newjack: Guarding Sing Sing (Conover 2001), Going up the River (Hallinan 2003), Crime Control as Industry (Christie 2000), and A Little Book of Restorative Justice (Zehr 2002). The students (both inside and out) were expected to read the assignments and be prepared to discuss them at the following meeting. Additionally, the professor prepared lectures, activities, and discussions on topics related to those readings. The course was fairly organized; nevertheless, with three hours of class, they were given plenty of time to diverge from this schedule as seen fit.

After each meeting, the students were expected to write two to five page papers with the following components: observations, analysis and integration, and reflections. The “observation” and "reflection” sections were intended to provide the students with a chance to voice their opinions about the class, the discussions, other students, or any other issues they felt warranted attention. Some students chose to only discuss the topics from the class meetings, while others included anecdotes about their interactions within the classroom. Also some students chose to use these sections to voice grievances about the class or the other students. The “Analysis and Integration” sections were designed for the students to integrate the assigned readings into the class discussions. As such, these sections were the more academically and applied knowledge portions of the papers. For the purposes of this research, I only chose to 
analyze the "observation” and "reflection” sections of the students” papers; since they did include the more personal perspectives of each person.

Towards the end of the course, the students were broken into groups compiled of university students and residents of the facility. The purpose of these groups was to formulate suggestions to the warden and the commissioner of the Department of Corrections to improve or change current policies. These suggestions were then presented to the officials and other correctional workers at a presentation after the completion of the final class meeting.

Since the start of this program in 2006, West Virginia University’s Division of Sociology and Anthropology has continued to offer this course to its students every semester, including some summer sessions. Additionally, Dr. James J. Nolan has continued to participate as the programs director and professor. At present, there have been about eight semesters of the Issues in Crime and Justice Program completed at West Virginia University.

\section{Significance of Program and other Programs within Prison Walls}

The Issues in Crime and Justice Program is founded on the belief that the two groups university students and prison residents - can benefit from a course combining the experiences and opinions of one another. Also, students will gain a better understanding of the importance and impacts of issues within the criminal justice system through hands-on and applied courses such as the Issues in Crime and Justice Program. Another important program guided by these same principles is the Inside-Out Prison Exchange Program founded at Temple University in 1997. $^{1}$

The Inside-Out Prison Exchange program’s website states that

\footnotetext{
${ }^{1}$ Information retrieved from Temple University’s Inside-Out Prison Exchange Program website.
} 
The original idea for this exchange among college students and people inside prison came from a man named Paul serving life in a Pennsylvania prison. He envisioned a space where the two groups could maintain an ongoing dialogue and delve into the root issues of crime together, where individuals could ask questions, address stereotypes, and examine criminal justice literature - in the context of honesty, authenticity, and trust. Since then, Inside-Out has done that and more. (Temple University)

Temple University has continued to offer this course since 1997. Furthermore, the university offers training seminars to other institutions interested in participating in or designing an InsideOut program at their respective colleges or universities. Although Temple University was the pioneer of this unique program, college courses have been offered to prisoners for many years. McCollum (1994) states, “College programs have a long history in U.S. prisons but their acceptability has ebbed and flowed over the years. College programs seem to have been in place in U.S. prisons shortly after the end of World War II in 1945” (McCollum 1994:55). Although the inclusion of college courses in prison programming increased during the 1960s and 1970s, they suffered an enormous decline in the 1980s and 1990s (McCollum 1994). According to Batiuk, Lahm, McKeever, Wilcox and Wilcox (2005), this decline in the inclusion of college courses may be an effect of the Violent Crime Control and Law Enforcement Act of 1994. The act

Contained within it a provision that denied the allocation of federal Pell Grant dollars to inmates. While the bill did not deny college programming to inmates, few prisoners have the resources to pay for college classes. As a result, many colleges and universities have had to close down their prison programs altogether. Batiuk et al. (2005:56)

Ultimately, the loss of funding may have resulted from the lack of support for the idea that the education of prisoners helps to reduce recidivism. In his infamous article “What Works? Questions and Answers about Prison Reform”, Robert Martinson $(1974: 25,49)$ told the public that "with few and isolated exceptions, the rehabilitative 
efforts that have been reported so far have had no appreciable effect on recidivism” and that "our present strategies...cannot overcome, or even appreciably reduce, the powerful tendencies of offenders to continue in criminal behavior”. His famous report caused prison officials and policy makers to throw their arms in the air and declare "Nothing works!” So if nothing works, what is the point in allocating money to useless endeavors? However, Gaes, Flanagan, and Stewart (1999:361) state “Education, vocational training, and prison labor programs have modest effects on reducing criminal recidivism and increase positive behavior in prison”. Even Martinson (1979) himself eventually came around to the conclusion that some forms of treatment do have a positive impact on recidivism rates. Gaes et al. (1999) point to the fact in their article that the current research support the idea that prison programming and treatment do actually seem to aid in the reduction of recidivism.

The evidence seems to point to the continuing need for prison programming and education, just like the Issues in Crime and Justice Course. Even with all this evidence aside, this program does offer a unique experience for all involved. It may not effectively help every single prisoner, but just the mere chance of it helping is reason enough to continue allowing participation.

\section{METHODS AND DATA:}

During the Issues in Crime and Justice Program, the professor would begin each class by prompting a particular topic of discussion. The discourse included topics ranging from the construction of a criminal label to the perceived purposes of prison. The professor, along with brief lectures, planned activities revolving around these topics of discussion. The structure of the class allowed sufficient time for all students’ opinions to be heard. The resulting reflection 
papers included the students' observations, perceptions, and opinions on all of these interactions within the classroom during the specified week.

The ultimate goal of this project was to gain a better understanding of how the students within the Issues in Crime and Justice Course perceive and view current policies. Moreover, I wanted to attempt at an explanation of the difference in perceptions between university students and residents of a correctional facility. Through these explanations and descriptions, I hoped to construct a theoretical framework of their combined views about the criminal justice system. The most accurate way to gain access to those internal and private opinions would be through their own reflections of the class. These papers allow the reader to intercept a piece of the students' internal dialogues throughout the course, directly from the source.

This research is based on the analysis of written papers from the course. The participating students were required to turn in eight papers each. In addition, the final paper included their overall opinions and reflections of the entire course; whereas, the remaining seven papers were reflections upon individual classes. The university students' papers were graded to be included into their final grade. Therefore, in order to be successful in the course, they must have completed all eight papers. On the other hand, the residents of the correctional facility were not receiving a grade for their papers. Upon completion of the course, they were simply given a certificate of completion. Since they were not required to turn in a paper, not every prisoner turned in a paper every week. The amount of papers received from the prisoners was more sporadic than those of the university students. Altogether, there were about 70 papers returned, ranging from two to seven pages each.

This research employs an inductive method. As such, this project was solely driven by the data (the students' reflections) and the research and literature on the topic. A deductive 
strategy begins with propositions or assumptions stated as hypothesis which are then tested. In order to keep the core meanings and definitions of the students, it was imperative to avoid this deductive method. This does not mean that I did not begin the analysis without particular questions in mind (i.e. differences in perceptions between university students and prisoners); rather, I did not hypothesize or assume particular answers to those questions.

Although I had preconceived notions of how the data should look, provided through current literature, I did not allow these ideas to drive my analysis. Instead, I allowed myself to be guided by the data. Emerson (1995:110) warns researchers of the risk of imposing exogenous meanings upon our research data: “Ethnographers may use a term, category, or evaluation that is recognized, used and honored by one group in a particular social world to describe features or behaviors of another group in that world”. Although my research is not ethnography, it does help shed a light on the risks involved and obstacles that are faced in other qualitative studies. The ultimate goal of this research is to understand and dimensionalize the meanings and perceptions of the students. In other words, as a sociologist I cannot attempt to impose my discipline's language or jargon into another discipline’s world. By imposing outside meanings, I can possibly lose those members’ meanings. Howard Becker (1998:85) discussed the importance of preserving members’ meanings: “Careful description of details, unfiltered by our ideas and theories, produces observations that, not fitting those categories, require us to create new ideas and categories into which they can be fitted without forcing”. Through the construction of new and non-conventional categories, a researcher can be assured that nothing has been lost or ignored throughout the data.

The first step in my analysis was open coding. During this phase, I read through each paper, line by line, word by word. For each of these sections of data, I tried to find the best word 
or phrase to represent the students' thoughts. In this beginning step, I was not looking for anything in particular; but just keeping open to anything found within the analysis. After going through each student's paper, I began to notice certain themes or codes were repeating. As such these codes moved to the forefront of my analysis. I began to resituate my data collection around these reoccurring themes, or theoretically sampling. Corbin and Strauss (2008:195) define theoretical sampling as "data collection based on concepts that appear to be relevant to the evolving story line”. The ultimate goal of theoretical sampling is saturation. In other words, the goal is to look until there is nothing else to find. This action of theoretical sampling brings us around to the second stage of analysis: axial coding.

Axial coding is the "crosscutting or relating concepts to each other" (Corbin and Strauss 2008:195). Those reoccurring concepts were examined more closely and contrasted to other instances of the same concept. The key at this point is to continue asking questions of the data. What else do I need? What else could be useful to this relationship? Why is this important? These questions help to point the researcher to new and relevant data. This process will continue to develop until they are confident that sufficient data has been collected to explain each concept.

Although a section of data may look the same for two students, they may actually have had two very different intentions or underlying meanings. Another feature or technique of grounded theory is constant comparison. The researcher is continually looking over the data and comparing concepts to one another and searching for possible relationships. It is important to note that the steps of coding are not mutually exclusive. The analyst should always revisit the data and check the categories that have been identified. Perhaps s/he is missing something useful. Or maybe there is a relationship between concepts that has been over looked. 
The final stage of analysis is integration (Corbin and Strauss 2008). During this stage, I had to begin formulating a theoretical framework for all of the important concepts within the data; in other words, how all of the data relates to one another. The question most asked during this phase is “So what?” and "Why do I care?” Again, as with other portions of the analysis, it can be very difficult to filter and sift through all of the emerging concepts and themes. However, I found that the construction of diagrams and matrices were the most useful method, as will be seen in the "Findings" section of this research.

Before addressing the possible criticisms of my chosen method, I wish to briefly mention some of the strengths of grounded theory. First, grounded theory is durable. It seeks to accomplish this by seeking out all variations within the data. Moreover, these variations are incorporated into the findings. When using grounded theory, disparities within the data are never assumed as error, nor are they ignored. Another strength of grounded theory is its flexibility. Because a research is not starting out with preset schemes or theories, their puzzle is free to change as the data emerges. As a researcher comes to a dead end, they can begin to explore new alternatives. Finally, Corbin and Strauss (2008) also suggest that under grounded theory all knowledge functions as data. Therefore, literature can be a very fundamental part of research.

One issue that may stimulate criticisms with my methodology would be validity. Validity always comes into question within social science, especially upon research that utilizes inductive qualitative methods (or grounded theory). Using an inductive approach of coding implies that the researcher will not begin with preset concepts. Instead they develop concepts and themes as they examine the data. As a result, every researcher may code the same data differently depending upon their relative interests. Because of the lack of consistency, some researchers may toss out an inductive inquiry for the sake of validity. 
It is important to understand that validity does not carry the same meaning in both quantitative and qualitative research. Rather, the issue in qualitative research is credibility rather than validity. Corbin and Strauss (2008) see research as being valid when it accurately represents the puzzle that is being studied or theorized. The way to validity is by completely immersing yourself into the data, being flexible, and exhausting every possible explanation. And during this immersion, we remember to look for cases that do not fit. Upon conclusion of the research, the researcher feels confident their conclusion is reasonable because they have investigated every possible angle of the social phenomena. My research project will be guided by this perception of validity.

Again, I must reiterate the important of the use of inductive inquiry for this research. The purposes of inductive examination is to explore meanings, and this is vital to the greater body of literature because as I've discussed, it is the meanings of "crime" and "criminal" that are evolving that we must keep up with and understand. And I truly believe that if I had chosen to uses a deductive approach to this research, then the students' core perceptions and definitions would have been lost under my imposition of meaning.

A second criticism of the present research may simply be with the data itself. With any scientific inquiry, the reliability and credibility of the work must first be proven through the choice of data. If you choose data that does not accurately represent what you are trying to explain, then the rest does not matter. However, as stated earlier, I do believe that these papers offer an exceptional view into the perceptions of the participating students. Additionally, because they are written papers, it provides a well documented timeline of evolution in those perceptions. Nevertheless, these positives do not protect this work from possible criticisms. I will discuss two such criticisms here. 
First, there is the issue of presentation of self. The university students are trying to get a good grade in the class, so it may be assumed that they will just say what they believe the instructor wants to hear. Although less structured, the same could be said of the inside students. Perhaps they wish to impress their instructor, therefore, they limit their comments to those comments the instructor will approve. With regards to this first criticism, I do not see this as a criticism that is only limited to data such as mine. Instead, I see the presentation of self dilemma as a problem for any fieldwork investigations: namely, interviews. In her discussion of the presentation of self, Riessman (1990:374) stated "Yet narratives are always edited version of reality, not objective and impartial descriptions of it and interviewees always make choices about what to divulge”. Even so, the interviewee (or student) still offers the researcher a glimpse into how they construct and make sense of their worlds and their interactions. A person may tidy up their home before having visitors, but the trained visitor can still find instances of untidiness. Brewer (1994:408) states “an ethnographer (like all social scientists) can only persuade the reader to agree that the explanation is a plausible one, but not that it is the only plausible one”.

A second possible criticism of the data is that these students were prompted about which topics to discuss within their papers. Each week the professor would bring up a topic (i.e. the purposes of prison) and ask the students to discuss these during the class. As such, the students were expected to reflect upon these discussions relating to those chosen topics. Some may say that I am not given a complete glimpse into the students’ perceptions of crime and justice, but rather a one-sided glimpse into those topics which the professor felt were most appropriate for the class. This criticism may not be completely unfounded; because after looking through all the data, there is a fairly consistent amount of certain topics discussed by the students at certain times throughout the semester. However, within the "reflection" and "observation" sections of 
the papers, the students were allowed to discuss pretty much whatever they chose. Therefore, sometimes they did not limit their discussions to the topics pertaining to the class. Additionally, one could also relate this criticism back to those of interviews. Some interviewers may choose to construct an interview guide, or prompt certain questions. The reason for this is that it provides a little bit more consistency and form to the resulting data. If there were not some type of guidance, these interviewees and students may be free to roam wherever they wish. Again, I do not see this criticism as being so great as to completely disregard the ultimate findings of this research.

\section{FINDINGS:}

Following the principles of grounded theory, two major concepts merged from the data, found to be most pertinent to the "evolving storyline". These themes were 1) the social construction of the labels "crime" and "criminal” and 2) the purposes of prison.

\section{The Social Construction of “Crime”: Criminal vs. Martyrdom}

During week two, the professor prompted a discussion of the idea that "crime" and "criminal” are socially constructed realities. Insofar as these words or labels, cannot be empirically identified, but that they are created "truths". This relates back to earlier discussions of Reiman's (2007) concept of the "carnival mirror”. The idea being that there is no such thing as a criminal without crime and vice versa. We as a society depend upon our criminal justice system to decide which actions are so detrimental to our well being that they should be considered "criminal". The professor was hoping to drive this point home by explaining that the inside students were not actually criminals; but that they were people who simply made poor choices. After discussing these concepts, the professor opened the floor to the class to gain their perspectives on the topic. 
The discussion within class led an outside student to question our society's view on "crime". This student began to wonder why we as a society place more importance on "street crime" rather than "white collar crime". She believed it was because we place more importance on the "value of human life". In other words, street crimes are considered more dangerous because they sometimes result in physical harm or death to human beings. Because street crimes are much more visible to the general public, more significance is associated with them. But from this she begs the question: do white collar "criminals" not sometimes harm and sometimes kill people as well? She stated, "White-collar crime is far more costly and victimizes far more people... and white collar crime should be punished in a harsher manner”. An inside student agreed with this: "The inconsistency of the punishment of white collar and street level crime creates even more problems. By only punishing the poor and the turning the head effect used toward white collar crime we are creating much animosity and disrespect for the criminal justice system”.

The students within the class also discussed the construction of the label "criminal". It was very interesting to find that even the inside students rely on the "carnival mirror", and define themselves as "criminals". Therefore, not only are those outside of the criminal justice system accepting our society's definition of "crime" and "criminal", but also so are those who are most affected by the system.

During week three, the class participated in an activity where they read a story and had to decide whom was the worst or the most "criminal”. A female inside student realized during this activity how much everyone’s opinions differed. She stated, "Personal convictions, morals and ethics strongly affect one's perception of the law and what is criminal." She began to understand how much personal experiences can affect ones definition of what and whom is "criminal". One 
particular university student attempted to identify with those insiders unwilling to castaway their “criminal” labels. She stated,

When [inside student] described why she was incarcerated I couldn't help but think I might have done the same thing in her situation. I mean to sit back and watch as justice isn't served, I don't really know how I would react, but it might have been similar to how she did. And when [inside student] called himself criminal, there are things I have done that were criminal. (Outside Student: Week Three)

During this discussion of "criminality", the outside students explained this concept of the "carnival mirror" and the social construction of "criminal” to the inside students. One inside student found this explanation amusing. He felt as if the outside students were just simply being nice, and trying to boost his ego. However, he stated "it was very kind of them but I am aware of my current status, and for the most part I accept the position I put myself in”. It seemed as though this student, despite the efforts of the university students, felt as though his status and position was simply that of a prisoner and criminal. Moreover, he was fully accepting and embracing this new status. Another outside student was saddened by these inside students' willingness to accept the label "criminal". This student stated

Instead of thinking of himself as a man, a West Virginian, a father, a brother, a son, or even as [his name], he thinks of himself first as a criminal. I think this is the true failure of the system, it strips away the inmates' dignity and does not set them up for reintegration upon release. (Outside Student: Week 4)

Although many of the inside students did not understand or agree with the professor's explanation of the construction of labels, one inside student stated he had never thought about it before the class. He stated,

I agree on many levels with [the professor] that a person should not be labeled a criminal. This term has such a negative connotation and truly could be applied to most people in our society. It is not fair to characterize a person by the mistakes they have made or by the choices, right or wrong, picked by people. I believe that characterizing human beings as criminals is the root of the current problems faced by the penal system. (Inside Student: Week Three) 
A female outside student agreed with this assumption of failure, and felt as though these inside students were practicing the self-fulfilling prophecy. If this student is correct, these offenders accept the label "criminal". As seen from these few students, they begin to internalize the term "criminal". Before long, if not already, they will assume the duties that the role of “criminal” requires. This assumption of roles will help to fuel the revolving door within our criminal justice system. As such, these insiders do not stand a chance of succeeding on the outside. During week three, one particular inside student stated, "I have always felt I would end up in Prison!” He goes on to say that his criminal lifestyle is “...the only way I know”. With this type of attitude, does this student have a possibility of living a different life?

One outside student observed an inside student's frustration with the topic. She stated, "He cannot understand the concept that nobody is a criminal, that they are just a person that committed a crime. He has it so ingrained in his mind that he is a criminal that there is no way of changing his way of thinking.” This student realized although they are trapped in an undesirable situation, they are still unable to see past the "carnival mirror". Additionally, it seems as if this particular prisoner feels that by accepting the label of "criminal", then he is accepting responsibility for his offenses. Perhaps he is sacrificing himself and his identity as way of "paying for his debt” in some form of martyrdom.

The concept of martyrdom could also be seen very clearly by an inside student through his reflections of the first class. He stated for the successfulness of the course, it was important for him to be honest about his past. He stated,

I think if outside students are going to reap the full benefits of my perspective as an inmate, and someone who has experienced the criminal justice system starting in my early teen years and continuing into my adult life, then I need to be completely honest and open...I think it's essential that I reveal as much of my true self to them as I can, and not to sugarcoat my crimes, and or my criminal 
addictive thinking and behavior...I must cast away any personal shame that I feel in regards to the crimes I have committed. (Inside Student: Week One)

Perhaps all the inside students were acting as martyrs. In the beginning of the course, a lot of the inside students mentioned some feelings of apprehension about participating in the program.

They were hesitant to share their stories for fear of being judged by the outside students.

Nevertheless, these students chose to participate, and a few stated that they felt their stories could help. As such, they chose to sacrifice their privacy and pride for the betterment of the course.

\section{Differences' in the Perception of the "Carnival Mirror"}

Through the analysis and discussion of the students' responses to the professor's notion of the social construction of labels, it becomes clear that there were differences in perspectives between the two groups (inside and outside). The university students seemed more willing to accept and agree with the belief that crime and criminal are socially constructed realities. In fact, as the "Findings" section illustrates, they were so convinced that they tried to explain this theory to the inside students. Additionally, they became angry and frustrated when the inside students refused to agree with them.

On the other hand, the inside students were less eager and willing to accept that they were not actually “criminals”. One inside student felt as though the university students and professor were just trying to be "nice”. Again, this points us back to the concept of martyrdom discussed earlier. These prisoners' unwillingness to drop their criminal identities seemed to relate to their need to accept responsibility for their offenses. One would think that a person would be more than eager to erase such a negative label. However, these prisoners seemed unable to grasp that possibility. This causes one to wonder how it is possible that this labeling process can run so deep into a person’s personality. 
It seems as though it is easier for individuals outside of the criminal justice system to adapt their opinions and even acceptance of the "carnival mirror”. They were willing to change this view of "criminal" within the first few weeks of class. On the other hand, the few inside student who did adapt their view of "criminal", took much longer to change their opinions. From these findings, it appears that incarceration is the missing variable. Perhaps prison is functioning as an enforcer of the labeling process. This could be through the available programming at the prison, or lack thereof. Also it could point to the types and essentiality of the available individualized treatment (i.e. through counseling).

\section{The Purposes of Prisons}

The second, and perhaps most significant finding that emerged during the analysis of the students' papers, was the purposes of prisons. During one of the classes, the professor posed the question "What are prisons for?” An inside student was surprised to find the entire group "struggled to answer what is seemingly a simple question". The answers to the question were completely different, depending upon who was asked. However, most students provided wholly negative responses to the discussion of the purposes of prisons. Is it surprising that those individuals affected most by the system were negative about the system? Why do those individuals who have not experienced life in prison feel so negative toward the system and its relative effectiveness?

Most of the students did provide negative purposes of prisons. However, while the inside students' contributions to the discussion of the purposes of prisons were entirely negative, the outside students did in fact provide two positive purposes. Nevertheless, there were some purposes of prisons discussed upon which both groups agreed. The responses that both groups agreed upon were also completely negative. These purposes of prison are provided in Chart 1 
organized according to who contributed the responses. Additionally, these findings will be discussed below along the same lines.

\section{Comparative Perceptions of the Purposes of Prisons}

During the discussion of the purposes of prison, both inside and outside students saw prison as a rite of passage. An outside student agreed with the inside students when they stated that prison is often "glorified" and seen as a rite of passage (especially for men). This outside student stated that she herself "knew people who would brag about being arrested and felt that they were 'cool' for moving through the criminal justice system”. Another outside student observed that this idea of glorifying prison can be seen by the adaptation of "prison fashion" on the outside. This student stated

They wear their sagging pants, wife-beater shirts, and their tattoos are all over their arms and chests; and they really think they're cool. They are going for the gangsta look and they achieve it, all except for having never been in prison or done anything gangsta in their lives except sag their pants. Looking like you've been to prison is just as cool in their minds as having actually been there. (Outside Student)

Another university student observed that one of the inside students felt that "the people in his environment saw [inside student] as a 'man' because he was spending time in jail...To his neighborhood, going to prison is something all boys must do in order to become men”.

Both outside and inside students also saw prison as a "school for illegal activity". In this “school”, prisoners learn new "trades" and gain a "criminal” education. An inside student acknowledged that this is one of the negative functions of prison life. A male outside student shared this observation by stating, "For the most part, they agree that the prison system makes you more of a criminal than when you first get sent there”. Some outside students observed the inside students felt that this school of "crime" could be prevented simply by separating the firsttime offenders and repeat offenders. By doing this, they believed there would be a decrease in 
the recidivism of these first-time offenders. An inside student stated that she had seen things in prison that she had never seen before in her life. This inside student felt "being a con-artist gets you further, and that some guards encourage that behavior”. Therefore, it would seem that this school of "crime" is being encouraged by the prisoners and the officers.

Finally, both groups of students saw a function of prison as "prison as industry”. The professor assigned Nils Christie’s (2000) book, Prison as Industry during the Issues in Crime and Justice course. Therefore, this could explain why this was brought up as a purpose of prison. However, the students did elaborate on this idea. Construction companies, phone companies, and other big businesses are able to reap the benefits of such high incarceration rates in the U.S. An inside student stated, "with the virtually endless supply of crime it is no wonder crime control has become such a high industry”. This student goes on to discuss how the construction of prisons creates jobs. Building prisons in poor, rural areas where jobs are scarce force locals "to go to work at the expense of others”.

Some students recognized that the prisoners who are allowed to work outside the prison are a source of cheap labor for construction companies, road crews, and the like. Of course, these prisoners jump at the chance to leave the high fences of the facilities to work. The companies who hire these individuals do not hesitate to take advantage of their desperation. One university student stated

If they are doing work equal to outside workers, they deserve the same pay. They shouldn't been seen as cheap labor, they should be seen as reliable labor. They have reliable transportation, they have the desire to work and be off grounds, they will do the work knowing that if they don't they won't be allowed to go off grounds anymore. (Outside Student: Week 3) 


\section{Contrasting Perceptions of the Purposes of Prisons}

Inside Students' Perceptions. For the remaining two purposes of prisons mentioned within the class discussion were contributed only by the inside students. These two purposes were: 1) protection for the offender and 2) a human warehouse. Many of the outside students were saddened and surprised by these contributions by the inside students.

The first contrasting purposes of prisons offered by the inside students is safety and protection: protection for the offender rather than society. "Hiding out" was provided as a purpose for prison by one inside student. She felt that some used prison as a place to "hide” from their problems on the outside. Maybe they lack the skills to participate in legitimate ways in society, so instead they turn to a criminal life. But while in prison they do not try to gain these skills. She felt that this was definitely true for herself. This student stated "In five years incarcerated I've closed the world out and have refused to take the necessary steps to remove myself from my 'comfort zone'”. In other words, while in prison she has not chosen to try and take advantage of her situation and try to improve her life on the outside. Prison is a way to protect these individuals from an unsuccessful life on the outside. Perhaps this view of prison comes from their acceptance of their "criminal” statuses. The shame these prisoners carry inhibit them from being able to change their courses.

The second contrasting purpose of prison is the use of prison as a "human warehouse". Many of the inside and outside students felt as though the main purpose of prison was to "storeaway" the "criminals". These students feel this way because there are little to no attempts at actually reforming or rehabilitating prisoners. As an outside student stated, "Prisons were supposed to be places [where] those that have committed crimes can go and be rehabilitated in 
order to possibly re-join society some day. Instead, prisons are now in the full sense of the term, 'human warehouses'.”

One university student was "saddened to hear that one of the inside students felt that prisons act as human storage, a place to keep all the bad, unwanted people of society”. It seems as though the students view prisons as more of a "waiting game": waiting to move, waiting to be sent back to their lives. These prisoners are not learning how to become more productive or legitimate members of society, but rather they are simply waiting.

One inside student elaborated upon this idea of "human storage” by incorporating Nils Christie's (2000) comparison of Hitler's Holocaust to America’s excessive use of incarceration. This student stated "I see this as simply a more modern and democratic way to purify the upper class in America.” Although the carnival mirror tries to convince society that they need protection from these offenders, they are really just separating the lower class and minorities of our society. Meanwhile, those offenders in the higher classes are escaping punishment for their offenses. The criminal law is working to the advantage of the upper classes.

Outside Students' Perceptions. The outside students also contributed original responses to the discussion of the purposes of prison. It was interesting to find that their responses were the only positive responses in the class discussion. They included: Protection for society and rehabilitation of the offender. Although the outside students felt these should be purposes of prisons, they admitted that it isn't necessarily true. Additionally, these positive purposes of prison were drowned out in the discussion by the more negative functions of prisons. One university student stated, “The first few answers were the generic safety and society, but then they got more in-depth and real”. In other words, the university students first provided these positive purposes of prisons, but then went on to mostly discuss the more negative purposes of 
prison. Another university student stated, "Prisons are for the public’s safety and to help rehabilitate the 'criminals' who are sent there. If you have ever talked to an inmate before though, you know that this is not entirely true”.

The university students did not expand upon these positive purposes of prison, but rather discussed how they were wrong. Perhaps these students' changed their minds because of the dialogues that took place with the inside students within the classroom. The last quote seems to point to the fact that the discussions with the inside students did impact her opinion and perception of the purposes of prisons. If the university students were asked the same questions, but without the inside students in the classroom, would they have provided only positive purposes of prisons? If so, it seems as though the interactions and discussions with the inside students did influence the outside students to change their opinions.

As the preceding findings illustrate, the outside students did contribute original ideas pointing to more positive purposes of prison. However, these positive responses were mostly hidden by the more negative responses. These outside students agreed and supported three of the five ideas presented by the inside students. Perhaps it was more difficult for the outside students to identify with the inside students because they had not actually experienced life in prison. Additionally, their training on the academic level may have influenced their answers. The following section furthers this discussion.

\section{Students’ Perceptions of the Purposes of Prison}

The discourse on the purposes of prison proved to be just the opposite of the discussions on the social construction of "criminal” with regards to the differences in opinions between the groups. Most had already formed their opinions before even participating in the course, while 
others' opinions adapted as the course progressed. There were three important characteristics of the data regarding opinions on the purposes of prison.

First, the analysis pointed to the fact that the two groups (inside and outside) seemed to agree more with regards to their opinions on the purposes of prisons. On the other hand, differences in opinions were found within the groups. For example, those who had experienced prison seemed to have differing views of why prisons existed. Furthermore, they disagreed as to whether or not they should exist. The same could be said for those individuals who have not experienced prison. They each had prior opinions about what they felt were the purposes of prisons.

Secondly it seems as if both groups seemed to focus on the more latent and indirect purposes of prisons. After first reading through the students' observations, I was surprised to find that relatively few agreed with the guiding literatures take on the functions of prisons: especially surprised by the university students' responses. I had expected, due to their more classical and academic training, the university students to provide responses reflecting the literature they had read during other undergraduate courses. Nevertheless, the university students' responses were similar to the residents of the prison facility. The main differences between the two groups were that the personal experiences that influenced their answers. For example, those who had been incarcerated where more likely to use personal anecdotes to support or illustrate their opinions than those who had not been incarcerated.

A final characteristic of the data on the students' perceptions of the purposes of prison was that all, but a few, saw prisons as almost entirely negative institutions. These types of negative views of prison were fairly consistent across both groups. For the outside students, it seemed as though hearing the inside students' stories of live in prison solidified their negative 
views of prison. It was almost as if the discussions within the classroom gave them more evidence of the negative impacts of prison. On the other hand, it is important to mention that one university student admitted that he felt the prisoners deserved the negative aspects of prison because of their behavior. However, towards the end of the class, he did say he was wrong for those initial feelings; and furthermore stated that prison should be punishment in and of itself.

These findings point to the importance of exploring members' meanings and their developing notions of the criminal justice system, and how our society views those issues. It proves that although those incarcerated individuals have had different experiences than most members of society, they are not all that different in how they view their situations and the criminal justice system. Their personal experience offers an incomparable contribution to the understanding of the criminal justice system, and those that experience it. Moreover, their experiences help the outside students to gain a better understanding of how prison is actually experienced. And finally, the data seems to point to the idea that the opinions of outsiders and insiders are not that different, especially the way in which they arrive at their opinions and perceptions. More importantly, this research supports the assumption that these types of programs are invaluable for all who participate: insiders and outsiders alike.

\section{DISCUSSION:}

As stated in the above sections, I was surprised to find that the university students did not include the more "traditional" responses to the purposes of prisons. During their courses within the criminology major, some of the students may have taken applied courses that dealt with punishment and prisons. Usually these courses include discussions on sanctioning/punishment perspectives. After the analysis and discussion of the findings, I began to wonder if this research could benefit from the integration of these "traditional" perspectives and the perspectives of the 
students within the Issues in Crime and Justice Course. The following section explores this integration of perspectives.

\section{Integrated Perspectives on the Social Construction of "Crime" and "Criminal"}

The analysis of the discourse found differences in the students' ability or willingness to accept the professor's idea that “criminal” is a socially constructed idea. More specifically the inside students were more reluctant towards this idea. As the preceding section discussed, the inside students saw losing the “criminal” label as not accepting responsibility for their deviant actions. This finding led to the idea of martyrdom. Even the inside students' participation within the course could be seen as a type of martyrdom. Although they were hesitant and afraid of how they would be treated by the outside students, they felt that the outside students and the course itself could benefit from their participation. As such, they chose to sacrifice their pride and privacy for the betterment of the course.

This idea of sacrifice and martyrdom, led me to think about the acceptance of these socially constructed labels in a different way. Perhaps it would be more beneficial to think about the acceptance of the labels by who benefits from them, and who suffers. Some students felt that the class would be benefiting from their own sacrifices. Through this way of thinking, how do we members of society benefit from those individuals accepting the labels of “criminal”? We can think through this issue by considering it along two dimensions: 1) positive and negative consequences and 2) collective and individual consequences (Appendix B).

\section{$\underline{\text { Individual Consequences of “Criminal” Label }}$}

Positive Consequences. By the construction and acceptance of the label "crime” or “criminal”, there are two positive benefits on the individual level discussed within the Issues in Crime and Justice program. First, by society’s acceptance of the definition of a "crime” and 
"criminal", they are able to place blame. By knowing whom to blame, we know who to punish or rehabilitate (depending upon the guiding ideology). As one outside student stated, "I was told that those in prison are there because they are bad people, they're criminals and they deserve to be there, it's just a fact of life. Once a thief always a thief”. As this student demonstrates, she was brought up to believe that criminals are bad people that should be put away. The use of the label "criminal" allows us to distinguish between the "good" and the "bad".

Secondly, the acceptance of the label "criminal" forces the perpetrator to accept responsibility, as with the inside, "martyr” student earlier. That inside student felt that the acceptance of the "criminal" label was an acceptance of responsibility for his actions. By accepting the label of "criminal", the offender is able to begin either the transformation or containment phases of imprisonment. This acceptance of the label can oftentimes be seen in the way mental treatment is provided within the prisons. Many times these counselors offer the way of "salvation" through the acceptance of their statuses and situations.

Negative Consequences. There are also negative effects of the acceptance of a criminal label on an individual level. As Becker (1963) illustrated, the first step to labeling is being caught in the deviant act. Obviously, the prisoners participating in the Issues in Crime and Justice course have already accomplished this first step. Next, if an offender chooses to accept the label "criminal", they may then also choose to take on the roles of their label.

As one outside student mentioned, the self-fulfilling prophecy can help to explain this phenomenon. If an offender internalizes the criminal label, they may choose to continue their criminal activities once released. One inside student stated,

I mean my way of thinking and doing things is so engrained in my psyche, that I myself do have real doubts about being able to sustain any long term meaningful change in my life, sure I will be able to function in society like I always have, but it will be to some degree on my own terms and the undermining and the 
manipulating of the rules will always be an ever present determining factor in the way I conduct my daily affairs and come to my decisions. (Inside Student:

Week1)

The internalization of the criminal label leads into the second negative consequence of the “criminal” label: higher recidivism rates.

A third negative on the individual level of the acceptance of labels is the social stigma that those individuals will also suffer. After being labeled a “criminal” or a “felon”, a person’s access to opportunities is greatly stunted. Their past identity and skills moves into the background of their new criminal identity. A university student observed that most of the inside students were concerned about how they would be affected and treated on the outside: "Issues and questions the inside students had among themselves such as voting rights after release and questions on job applications asking about one's involvement in a felony”. One outside student felt as though this treatment after release from prison was unfair: “After they are paroled, they deserve the same chance at a happy and successful life as people who were never incarcerated; they did their required time and life after prison should be like a new start for them”.

\section{Collective Consequences of “Criminal” Label}

Positive Consequences. The acceptance of the definition of "criminal” also carries with it a set of collective positive consequences. These consequences are considered to be positive for the community or society rather than the offenders. One positive, but possibly incorrect, consequence of the acceptance of the "criminal” label is that by knowing who is considered “criminal” and what is considered a "crime”, society understands from whom and what they need be protected, as Reiman (2001) discussed.

An example of this that comes to mind is the sex offender databases. These databases are provided for anyone in the public to review. This list contains the names of sex offenders and 
the areas in which they live. Therefore, if a citizen reviews this list and finds that an area they are interested in contains a sex offender, they may choose to live elsewhere. A second assumed positive consequence of the acceptance of the definition of "criminal” is a reduction in crime. Because we know who is dangerous, we know whom to remove from society. As such, these presumably dangerous individuals are no longer able to commit crimes.

Negative Consequences. When considering the negative consequences of the "criminal label”, two possibilities come to mind. First, because we know whom to punish, there will be an increase in incarceration rates. An increase in incarceration rates may have a positive and negative consequence in and of itself. An increase in incarceration rates may lead to overcrowding of our nation's jails and prisons. However, this increase also means an increase in the construction of prisons, which leads to a boom in the prison industry. Therefore, there are individuals who may benefit and suffer because of the increase in incarcerated individuals. The second negative consequence of the acceptance of the definition of "criminal” is an increase in fear of crime.

The label "criminal” is such a vague and indeterminate concept that most anyone could be labeled as such. By informing society of who is “dangerous”, it may also cause some members to be frightened in their own communities. Through this fear, there may be a political and public push for an increase in harsher punishments. Again, an increase in harsher or longer punishments hikes the incarceration rates. These negative consequences are influencing one another in a cyclical fashion.

Concerning the inside students' unwillingness to let go of their criminal status, one should question why they are unable to move on. One would assume that those individuals would be more than eager to drop such a negative label. A label which, as the discourse 
illustrates, could affect them even beyond the prison walls. Whatever the source, it seems as though - at least in the case of these few prisoners - that imprisonment has caused these individuals to completely lose past identities and replace them with negative and cynical ones. As such, the "carnival mirror" has a much larger and permanent impact upon the "criminal” underworld.

This disconcerting finding causes one to wonder about the true impacts of the labeling process within the prison systems. If these individuals fail to see the other possibilities outside of the criminal lifestyle, then where will they end up after their release? They more than likely will not succeed, but will instead return to the prison within a relatively short amount of time. As such, it seems as though the pre-release programs should focus upon the possibilities available, rather than the action that landed them in prison in the first place. Furthermore, they must provide the skills needed to force these prisoners to be able to and to want to erase their negative, “criminal” master status.

\section{Integrated Perspectives on the Purposes of Prisons}

Thinking along the same lines, I theorized whether or not the concept of the purposes of prison could be broken down simpler. Therefore, I divided it along the lines of purposes versus consequences of prison. These two categories could then be divided into positive and negative purposes and consequences. This model is illustrated in Appendix C.

\section{$\underline{\text { Purposes of Prisons }}$}

Positive Purposes. The first quadrant of the matrix illustrates the positive purposes of prison as "transformation of the individual". The idea of "transformation" refers to replacing the "bad” or undesired behavior in the offender with "good” and more conventional behavior. Prisons attempt at transforming individuals formally through rehabilitation. In order to 
transform these individuals, the prisons may offer individuals programming to gain skills or education. Other prisoners may be enrolled in individual or group therapy. No matter which method is chosen, they all are aiming at getting to the core of why those individuals have chosen a "criminal" lifestyle. Moreover, these programs aim to prevent them from returning to that life.

Additionally, as the discourse could suggest, the prisons also transform some individuals informally through redemption. The idea of redemption could be seen through the inside students' unwillingness to drop their “criminal” statuses. This can be seen further through their capacity to participate in a course that could cause them pain (through judgment by others). As discussed above, rehabilitation aims to provide prisoners with skills and therapy that will help them to be successful and legitimate members of society upon release. Redemption aims to provide the individual with some "self-reflection" so they might accept responsibility. This redemptive aspect is an attempt to force the offender to pay for their wrongdoings.

Negative Purposes. The second quadrant of the matrix labels the negative purpose of prison as "containment". Prison physically removes individuals from society and contains them within its structure. Here again is the concept of "warehousing" the offenders. This warehousing of individuals removes them from the community in which they committed the crime. During this "warehousing” phase, the prisoners do not benefit from the positive transformation aspect mentioned above. Secondly, prisons incapacitate the offenders. Through incapacitation, the prison strips the prisoners of all freedoms they had before entering. Again, this does not attempt to transform the offender, but simply punish them. One particular inside student saw the negative effects of this containment:

People who enter in to prison for the most part have very little self worth or very low self esteem, and what ever good feelings that they do have are often quickly eroded by the cold and callous way in which they are treated...the inmate will often become hardened...this process does get progressively worse over the course 
of the incarceration and it further [contributes] to the de-sensitizing of the inmate, so instead of getting better and more aware of how his actions effect others, (which is what I think the definition of rehabilitation is) the inmate comes out of prison a lot worse than [when] he entered. (Inside Student: Week 8)

\section{Consequences of Prisons}

Positive Consequences. These "positive” consequences may not been seen to all as good outcomes of prisons. However, they can be considered good to the individual offenders, if they are relevant to them. The first positive consequence of prison is access to free services. Although they are not truly free, some offenders are offered physical and mental health treatment on the inside that they may never have had access to on the outside. One inside student stated,

Several people that I know have mental health issues, such as depression or drug addiction, that go untreated because they have no health insurance available to them...Perhaps many of the drug offenders who are presently incarcerated could have benefited from some type of mental healthcare. This would certainly be an alternative to prison. (Inside Student: Week 6)

Another inside student noted the importance and impact of the mental health treatment he had received: "I have become so aware of my own behavior in prison only by the on-onone therapy that I receive from the staff Psychologist, so in that regards I am grateful to the criminal justice system”.

The second positive consequence that was also discussed earlier is the obtaining of a label or status from their time spent in prison. Once they are released from prison, their friends and family are proud of the offender's ability to "do the time”. Instead of losing statuses, these offenders actually gain status from their time behind bars. As stated before, “doing time” is the way to become a man in these neighborhoods or communities.

The final positive consequence of prison is the obtainment of new “criminal trades”. This idea of "crime school” was contributed by both the inside and outside students. These individuals go to prison and learn from others how to become a better "criminal”. They may 
choose to sell a different drug, or they may find ways to avoid being caught again. These individuals are still being transformed, but not the way prison is intended to transform them.

Negative Consequences. Being arrested, convicted, and sentenced to prison also results in negative consequences. These are considered negative consequences to the offender. Some of these are the same as those labeled as "positive” consequences, but they also carry negative outcomes. The first is the stigma attached to being labeled a "criminal". Some of the consequences of this stigma is difficulty finding or maintaining a job. Most job applications require prospective employees to disclose whether they have been convicted of a crime. By simply stating "yes", they may even be given a chance to work at that particular business. By not being able to obtain a legitimate job, they may have to turn back to their "criminal” life. Secondly, those convicted of a crime may lose their right to vote during elections. The discourse illustrates that the prisoners are concerned with the effects of labeling.

A second negative consequence is prison as a "school for crime". By learning new “criminal trades”, prisoners are reversing any attempt to rehabilitate or transform the offender. Instead of learning new and positive skills, they are learning how to become better at what landed them in prison in the first place. These individuals will probably return to a life of crime once released back into society. In addition, the prisoners return to prison will cause an increase in the incarceration rates.

The third and final negative consequence is the dehumanizing affects of prison life. Once a person enters prison, they essentially lose their identity. This idea ties back to the concept of the "degradation ceremony”. Once the offenders' enter prison they formally have their identities stripped away. They become just like everyone else: from how they are treated to how they must dress. "Deviant persons are regarded as having undergone a degradation 
ceremony with the result that they have been relegated to membership in a deviant group” (Thorsell and Klemke 1972:393). These individuals have formally become members of the prison and "criminal" community.

In addition, because of the "prison industry", they are often exploited. This concept of exploitation could be seen in the inside and outside students' thoughts that "prison as industry" was a purpose of prison. Prisoners may be allowed to leave the facility for work release, but they work for little to no pay. However, most prisoners put up with the exploitation because it is the only opportunity given where they may leave the facility. Outside companies are not afraid to take advantage of the prisoners' situations.

These findings point to the importance of exploring members' meanings. It proves that although those incarcerated individuals have had different experiences than most members of society, they are not very different in how they view their situations and the criminal justice system. Their personal experience offers an incomparable contribution to the understanding of the criminal justice system, and those that experience it. Moreover, their experiences help the outside students to gain a better understanding of how prison is actually experienced. Finally, the data seems to point to the idea that the opinions of outsiders and insiders are not that different, especially the way in which they arrive at their opinions and perceptions. More importantly, this research supports the assumption that these types of programs are invaluable for all who participate: insiders and outsiders alike.

\section{CONCLUSION AND SUGGESTIONS:}

The preceding research attempted to explore the perceptions of university undergraduate students and residents of a prison facility of issues in crime and justice. Additionally, the research attempted to explore the differences in perceptions between the two groups. Finally, it 
provided the reader with a theoretical framework of the combined opinions of both sets of individuals. The findings suggest that there are vast differences between the groups' opinions concerning the social construction of "criminal" labels. More specifically, it is harder for the residents of the prison to change their perceptions of the "carnival mirror". On the other hand, the findings show that there is little difference in opinion about the purposes of prison - or its relative effectiveness - between the two groups.

As discussed earlier, the prisoners' inability to change the way they see themselves seems to point to flaws within the prison's treatment programs. In order for the prisoner's to have a chance at success on the outside, they must first believe that it is possible. They will not be able to see those possibilities if they continue to think of themselves as "criminals", especially if that thinking continues beyond the prison walls. As such, I think this research does suggest a need of a revaluation of the principles and policies guiding the current individualized and group treatment within the prison walls. However, I do believe that allowing participation in programs such as the Issues in Crime in Justice Course is a step in the right direction; and could possibly help with some of those issues.

Very few individuals within the correctional field or academia believe that the current prison systems are perfect. Most agree that there are many flaws within the system, and within the treatment of the prisoners. As this research has suggested, these views also cross over to university students and prisoners. It would be misguided to suggest that all of these negative opinions of the current punishment policies are unfounded. Although this research does not contribute substantially to the improvement of the system, it is founded on the right idea. The idea being that in order to continue to improve the current systems, we must continue to explore new ways of learning and thinking about crime and punishment. Those within academia are 
burdened with the duty to provide guidance to that new system. As such, no sociological or criminological inquiry or research is immaterial. 


\section{REFERENCES:}

Batiuk, Mary Ellen, Karen F. Lahm, Matthew McKeever, Norma Wilcox, and Pamela Wilcox. "Disentangling the Effects of Correctional Education: Are Current Policies Misguided? An Event History Analysis.” Criminal Justice 5(1): 55-74.

Becker, Howard S. 1963. Outsiders: Studies in the Sociology of Deviances. London: Free Press.

----- 1998. Tricks of the Trade: How to Think about Research While You're Doing It. Chicago, IL: The University of Chicago Press.

Brewer, John D. 1994. “The Ethnographic Critique of Ethnography.” Pp. 405-408 in Social Research Methods: A Reader, edited by Clive Seale. New York City, NY: Routledge.

Christie, N. 2000. Crime Control as Industry: Towards Gulags, Western Style. $3^{\text {rd }}$ ed. London: Routledge.

Conover, T. 2001. Newjack: Guarding Sing Sing. New York City, NY: Vintage.

Cooley, Charles H. 1964. Human Nature and the Social Order. New York City, NY: Scribner's.

Corbin, Juliet and Anselm Strauss. 2008. Basics of Qualitative Research. $3^{\text {rd }}$ ed. Los Angeles, CA: Sage Publications.

Dostoevsky, Fyodor. (1866|2003). Crime and Punishment. New York City, NY: Bantam Books. Durkheim, E. 1933. The Division of Labor in Society. Translated by G. Simpson. New York City, NY: Free Press.

----- 1973. Moral Education: A Study in the Theory and Application of the Sociology of Education. Translated by E. K. Wilson and H. Schnurer. New York City, NY: Free Press. 
----- 1983. "The Evolution of Punishment." in Durkheim and the Law, edited by S. Lukes and A. Scull. Oxford, NY: Martin Robertson.

Elias, N. 1978. The History of Manners: The Civilising Process. Vol 1. Oxford, NY: Basil Blackwell.

Emerson, Robert M., Rachel I. Fretz, and Linda L. Shaw. 1995. Writing Ethnographic Fieldnotes. Chicago,IL: The University of Chicago Press.

Erikson, Kai T. 1962. “Notes on the Sociology of Deviance.” Social Problems 9(4): 307-314.

Foucault, M. 1977. Discipline and Punish: The Birth of the Prison. Translated by Alan Sheridan. London: Penguin.

Gaes, Gerald G., Timothy J. Flanagan, Laurence L. Motiuk, and Lynn Stewart. “Adult Correctional Treatment.” Crime and Justice 26: 361-426.

Garfinkel, Harold. 1956. “Conditions of Successful Degradation Ceremonies.” The American Journal of Sociology 61(5): 420-424.

Garland, David. 1991. "Sociological Perspectives on Punishment.” Crime and Justice 14: 115165.

Hallinan, J. 2003. Going up the River: Travels in a Prison Nation. New York City, NY: Random.

Howe, Adrian. 1994. Punish and Critique: Toward a Feminist Analysis of Penality. New York City, NY: Routledge.

Martinson, R. 1974. "What Works? - Questions and Answers about Prison Reform.” The Public Interest 35: 22-54.

------ 1979. “New Findings, New Views: A Note of Caution Regarding Sentencing Reform.” Hofstra Law Review 7: 243-258. 
McCollum, Sylvia G. 1994. "Prison College Programs.” The Prison Journal 73(1): 51-61. Miller, J. Mitchell, Christopher J.Schreck, and Richard Tewksbury. 2006. Criminological Theory: A Brief Introduction. Boston, MA: Allyn and Bacon.

Musto, David F. 1999. The American Disease: Origins of Narcotic Control. $3^{\text {rd }}$ ed. Oxford, NY: Oxford University Press.

Pashukanis, E. B. 1978. Law and Marxism: A General Theory, edited by C. Arthur, translated by Barbara Einhorn. London: Ink Links.

Reiman, Jeffrey. 2007. The Rich Get Richer and the Poor Get Prison: Ideology, Class and Criminal Justice. $8^{\text {th }}$ ed. Boston, MA: Allyn and Bacon.

Riessman, Catherine Kohler. 1990. "Strategic Uses of Narrative in the Presentation of Self and Illness: A Research Note.” Pp. 371-375 in Social Research Methods: A Reader, edited by Clive Seale. New York City, NY: Routledge.

Rusche, G. and O. Kirchheimer. 1968. Punishment and Social Structure. New York City, NY: Russell \& Russell.

“The Inside-Out Prison Exchange Program.” Temple University Retrieved December 19, 2008. (http://www.temple.edu/inside-out/aboutus/index.html).

Thorsell, Bernard A. and Lloyd W. Klemke. 1972. "The Labeling Process: Reinforcement and Deterrent?” Law and Society Review 6(3): 393-404.

Zehr, H. 2002. A Little Book of Restorative Justice. Intercourse, PA: Good Books. 
Appendix A. Students' Comparative and Contrasting Perceptions of the Purposes of Prisons

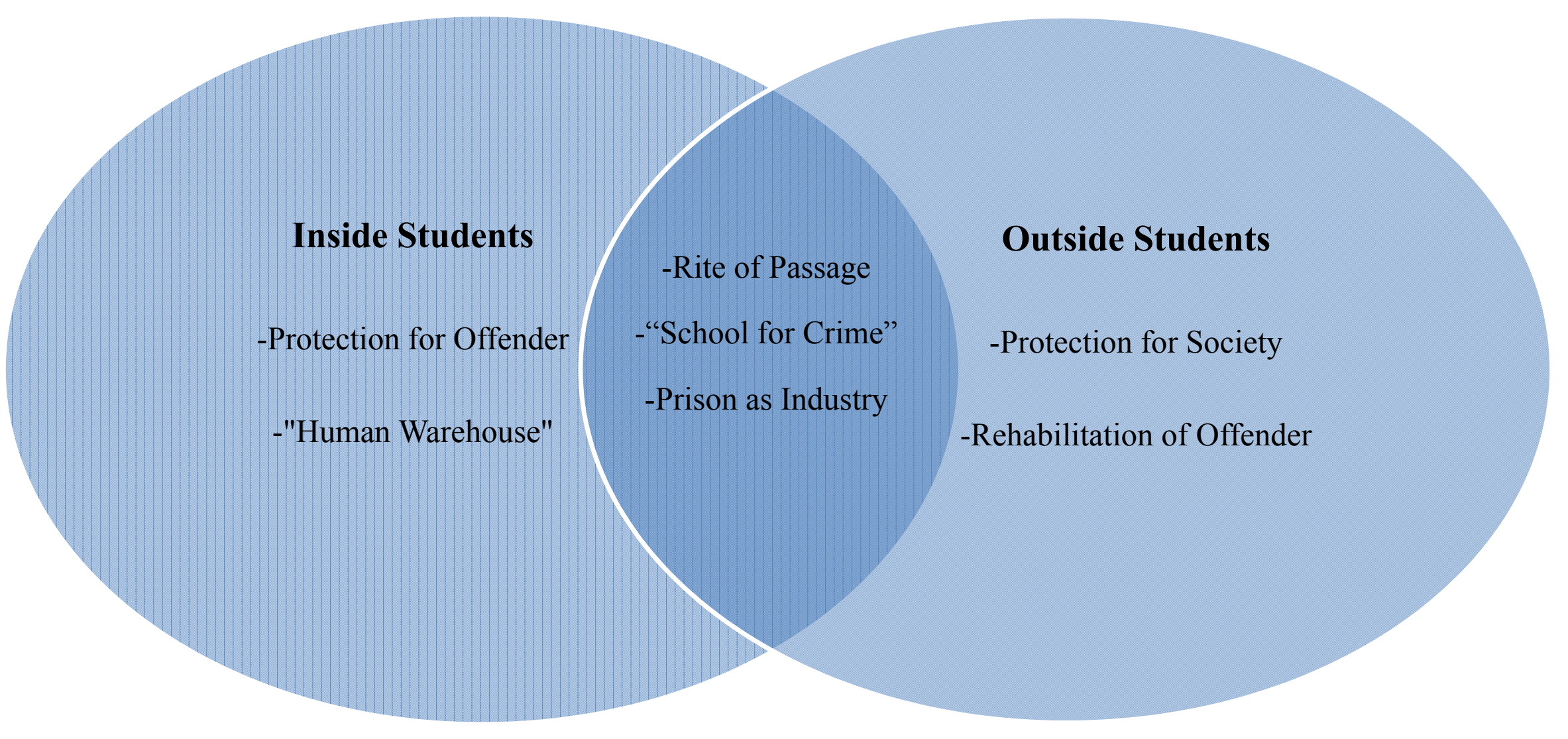


Appendix B.

Individual

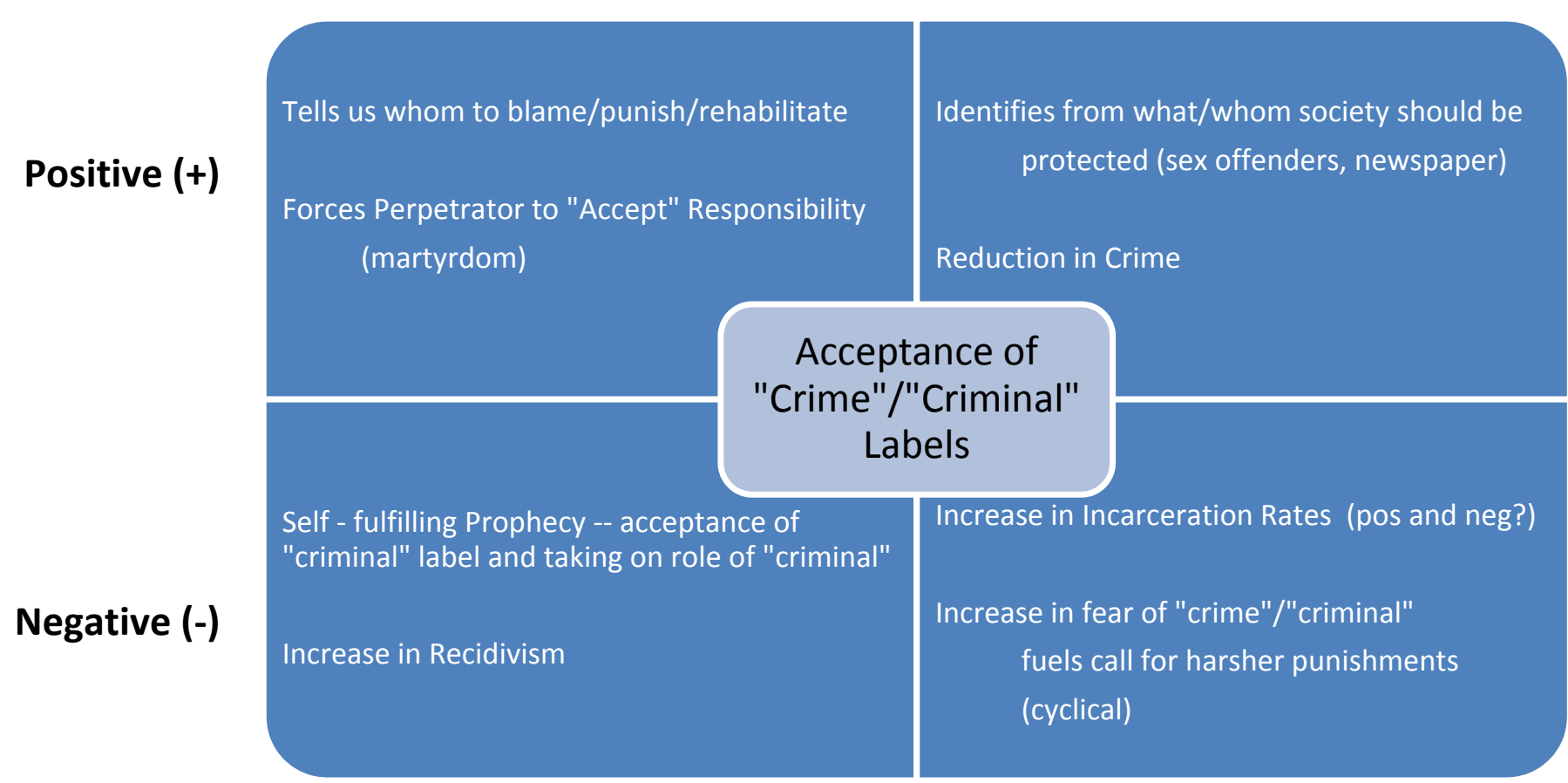




\section{Appendix C.}

Purposes

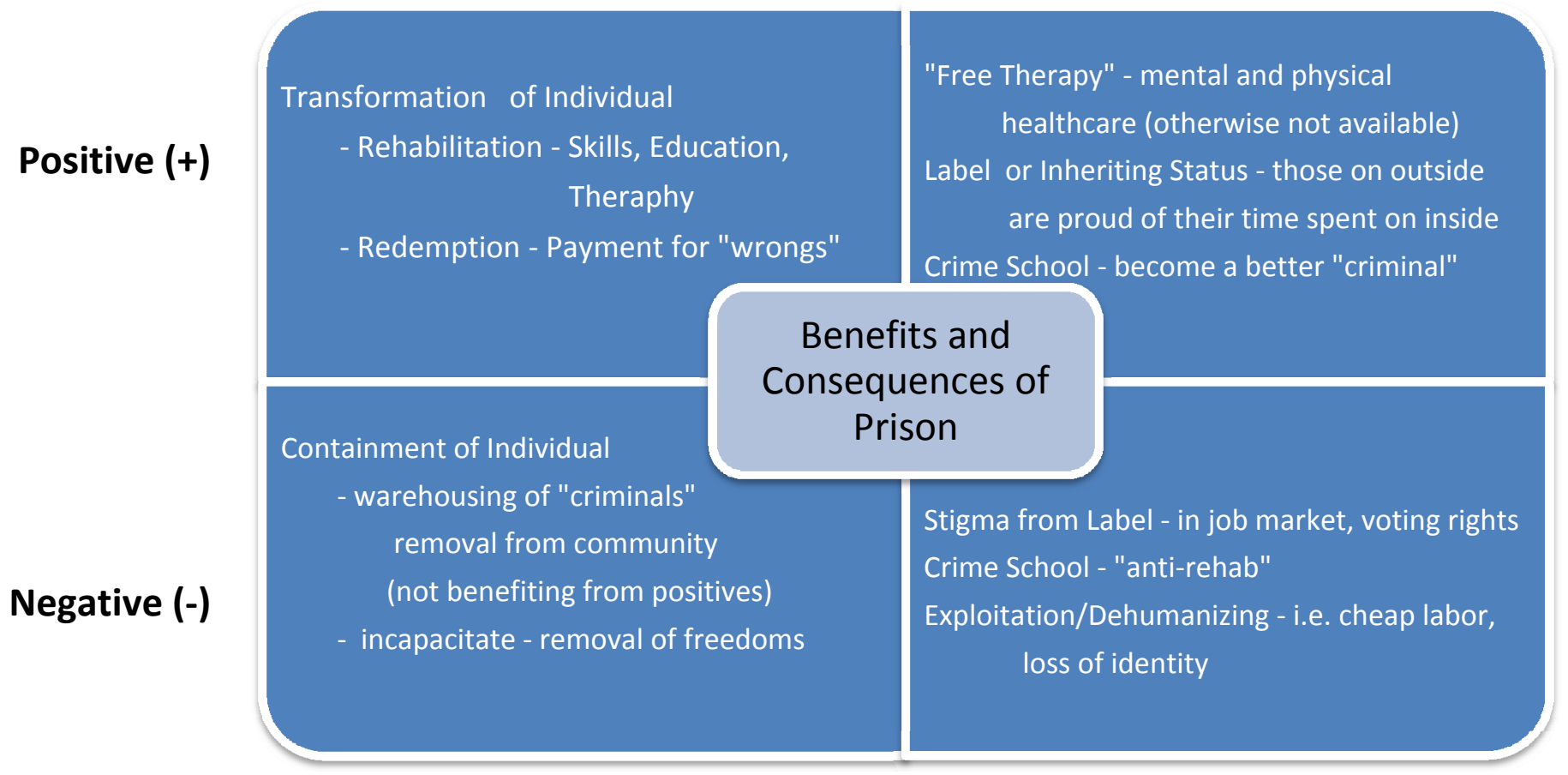

\section{Consequences}

or Inheriting Status - those on outside

Crime School - become a better "criminal" 


\title{
Kate Jessica DuBois
}

\author{
Master of Arts \\ West Virginia University \\ Division of Sociology and Anthropology
}

Permanent Address:

23085 Roberts Road

School Address:

Athens, $\mathrm{Al} 35614$

244 Riverview Ct. \#4

Morgantown, WV 26501

Email: kdubois1@mix.wvu.edu

Phone: (256) 777-9754

\section{EDUCATION}

2007-2009 M.A., Applied Social Research, West Virginia University

Thesis: Bidding at the Prison Auction House: An Exchange of Prisoners' and University Students' Perceptions of Crime and Punishment

2003-2007

B.A., Criminology and Investigations, West Virginia University

\section{EMPLOYMENT}

2007-present Graduate Teaching Assistant, Division of Sociology and Anthropology, West Virginia University

\section{RESEARCH INTERESTS}

Corrections

Prisoner Re-entry

Female Incarceration

Classification Systems

Community Policing

\section{HONORS \& AWARDS}

2008

2007-2009
President’s List, West Virginia University

Assistantship, Division of Sociology and Anthropology, West Virginia University 


\section{PRESENTATIONS AT PROFESSIONAL MEETINGS} Prison Walls.” Roundtable for Prisons and Social Problems North Central Sociological Association

\section{RESEARH EXPERIENCE}

\section{PROFESSIONAL ASSOCIATIONS}

American Sociological Association

American Society of Criminology

\section{RELATED COURSES COMPLETED}

\section{Graduate Courses}

SocA 510

SocA 517

SocA 693

SocA 511

SocA 513

SocA 518

SocA 697

SocA 698
Principles of Research Design

Data Analysis

Graduate Program Socialization

Survey Research Methods

Qualitative Methods

Data Analysis

Research Hours (6hrs.)

Thesis
$\mathrm{B}$

A

A

A

A

B

in progress

in progress

\section{Undergraduate Courses}

SocA 101 Introduction to Sociology B

SocA 105 Introduction to Anthropology B 
SocA 223 Death and Dying A

SocA 232 Criminology A

SocA 233 Juvenile Delinquency A

SocA 336 Sociology of Religion B

SocA 311 Social Research Methods B

SocA 293 Hate Crimes B

SocA 401 Sociological Theory B

SocA 402 Investigating Professions A

SocA 405 Introduction to Social Inequality B

SocA 389 Writing in Sociology A

SocA 461 Issues in Crime and Justice A

SocA 302 Deviant Behavior A

SocA 330 Criminal Justice System A

SocA 334 Corporate and White Collar Crime B

SocA 293 Prisons and Incarceration B

SocA 293 Female Offenders B

SocA 345 Terrorism B

SocA 495 Independent Studies (9hrs) A

\section{REFERENCES}

Sharon M. Latimer, Ph.D.

Chair, Division of Sociology and Anthropology

West Virginia University

315 Knapp Hall

Morgantown, WV 26506

(304) 293-5801

Melissa.Latimer@mail.wvu.edu

Corey Colyer, Ph.D.

Director, Masters Program of Applied Social Research

West Virginia University

313 Knapp Hall

Morgantown, WV 26506

(304) 293-5801 ext. 3207

Corey.Colyer@mail.wvu.edu

James J. Nolan, Ph.D.

Associate Professor, Division of Sociology and Anthropology

West Virginia University

300 Knapp Hall

Morgantown, WV 26506

(304) 293-5801 ext. 3210

Jim.Nolan@mail.wvu.edu 